\title{
EFFECT OF SPECIFIC HOST BODY PIGMENTATION ON THE NUMBER AND SPECIES COMPOSITION OF THE PARASITES OF GOLDEN SPECIMEN OF COD GADUS MORHUA L. FROM THE SVÅLBARD AREA
}

\author{
BEATA WięCASZEK ${ }^{1}$ and EWA SobeckA ${ }^{2}$
}

\author{
${ }^{1}$ West Pomeranian University of Technology, Dep. of Fish Systematics, \\ 4, Kazimierza Królewicza st., 71-550 Szczecin, Poland, \\ e-mail: bwiecaszek@zut.edu.pl \\ 2 West Pomeranian University of Technology, Dep. of Fish Diseases, \\ 4, Kazimierza Królewicza st., 71-550 Szczecin, Poland
}

\begin{abstract}
Parasitological examination was carried out on a single specimen of the northeast Atlantic cod Gadus morhua morhua L., of the unusual golden pigmentation, described for the first time in literature. It was collected together with commercially caught cod of typical colouration in the Svålbard Bank area. Only few endoparasites were found. The golden cod individual hosted five species of parasites: four species of nematodes (Anisakidae) and one of acanthocephalan (Echinorhynchidae). The species composition of parasites was probably affected by the specific golden skin pigmentation of the host.
\end{abstract}

Key words: golden cod, Gadus morhua, parasites, Anisakidae, Echinorhynchidae, Svålbard Bank

\section{INTRODUCTION}

The Atlantic cod, Gadus morhua L. (Teleostei: Gadidae) is one of the most important commercial fish species off the eastern and western coasts of the North Atlantic and due to this our knowledge of its life history and ecology surpasses that of most other fish species. Cod is intermediate, paratenic or definitive host to a large number of parasite species (107 taxa, reviewed by 
Hemmingsen and MacKenzie, 2001). The long list of cod parasites illustrates the omnivorous nature of its diet and its complex role within the food webs. Cod parasites and/or host-parasite interactions have been the subject of numerous studies. Most of them focus on various aspects of the parasite population variation, because the cod hosts anisakid nematodes of considerable economic and medical importance (Perdiguero-Alonso et al., 2008).

The cod varies widely in colour, but its colour phases fall generally into two main groups, the gray-green and the red. Adult fish inhabiting shelf waters of North Atlantic display a countershaded colouration: a dark back gradating to a light underbelly (Bigelov and Schroeder, 1953).

A single specimen of the Northeast Atlantic cod Gadus morhua morhua L., of a unique golden colouration, was collected in the eastern part of the Svålbard Bank area. There are no literature records of golden spotless cod.

The aim of this study was to ascertain the species composition of the parasite fauna of the golden specimen of Atlantic cod and its possible relevance to the pigmentation of the host fish body.

\section{MATERIAL AND METHODS}

A single specimen of the Atlantic cod Gadus morhua morhua L., of unique colouration, was collected in the eastern part of the Svålbard Bank, during the commercial cod catch $\left(76^{\circ} 20^{\prime} \mathrm{N}, 17^{\circ} 12^{\prime} \mathrm{E}\right)$, on 12 October, 2004. The depth of trawling ranged from 300 to $400 \mathrm{~m}$. The specimen was a female of total length $63.0 \mathrm{~cm}$, weight of $2030 \mathrm{~g}$, aged six years, in good condition (condition factor $\mathrm{K}=1.07)$.

During necropsy the following organs were examined for the presence of parasites: skin, vitreous humor and eye lens, buccal cavity, gills, heart, gonad, liver, spleen, gall bladder, alimentary tract, swim-bladder, peritoneum and muscles. The stomach and gut contents were studied by the decantation method. The parasites found were identified either from wet mounts (cleared in glycerol), or they were fixed and preserved in $75 \%$ ethyl alcohol, mounted permanently and then identified. The parasites were examined under Olympus BX 50 DIC microscope.

\section{RESULTS}

The general body tint of the cod examined was bright golden yellow above, fading to white on the belly and lower jaw, with golden head. None of greyish or brownish marks typical for Atlantic cod, was noted. All the fins were lemon yellow. At the base of pectoral fins was a black spot and the eyes were fully pigmented.

The parasite fauna of the specimen was dominated by generalists of Arctoboreal distribution. The examination revealed four species of nematodes of the family Anisakidae (Ascaridoidea, Ascaridia, Adenophorea): larval stages of 
Table 1. Infection structure of golden cod

\begin{tabular}{lll}
\hline Species & Location/microhabitat & $\begin{array}{l}\text { Number } \\
\text { of parasites }\end{array}$ \\
\hline Anisakis simplex L3 & On the stomach & 2 \\
Anisakis simplex L3 & On the gut & 2 \\
Pseudoterranova decipiens L3 & On the pyloric caecum & 4 \\
Pseudoterranova decipiens L3 & On the liver & 2 \\
Contracaecum sp. L3 & Stomach & 1 \\
Hysterothylacium aduncum L4 & Gut lumen & 1 \\
Hysterothylacium aduncum adult & Gut lumen & 2 \\
Echinorhynchus gadi adult & Gut lumen & 1 \\
\hline
\end{tabular}

Anisakis simplex (Rudolphi, 1809) Pseudoterranova decipiens (KraBBe, 1878) and Contracaecum sp. (L3), also larvae (L4) and adult males of Hysterothylacium aduncum (Rudolphi, 1802). An adult female of Echinorhynchus gadi Müller, 1776 (Palaeacanthocephala: Echinorhynchidae) was found as well. (Tab. 1).

\section{DISCUSSION}

The stomach of the golden individual examined contained only digested crustaceans (Decapoda, Pandalus borealis) (WIEcCASZEK et al., 2009). The stomachs of cod in the same length class, of typical body colouration, from the Svålbard area, contained mainly fish: herring and haddock (99.86\% of total stomach contents weight), while the proportion of the shrimp Pandalus borealis was very low. The contents of stomach of golden cod was thus probably unusual (WiĘCASZEK et al., 2009). However, in the Barents Sea cod predation is considered to be one of the most important factors influencing population dynamics of $P$. borealis; fish aged 3-6 had the maximum influence on the shrimp stock, especially during spring-summer season (BERENBoim et al., 2000). The golden cod was caught in a different period (October) and in this season cod of typical pigmentation fed almost exclusively on fish.

The analysis of metric characters of the cod examined revealed some differences between differently coloured fish, mostly in the head and neurocranium structure. The golden specimen's neurocranium was narrower and in one region markedly lower than that of typically coloured cod (WIĘCASZEK et al., 2009). According to JøRGENSEN at al. (2008) the skull bones are expected to reflect differences in fish feeding. Hitherto, in the Atlantic cod from the Barents Sea a total of 68 species or genera of parasites were recorded; these included 20 identified only to the higher taxon level (KARASEv, 2003). Pleistophora gadi Polyansky, 1944, Gyrodactylus cryptarum Malmberg, 1970, and G. emembranatus 
(Malmberg, 1970) are specific for the Atlantic cod (Hemmingsen and MacKenzie, 2001). The remaining species are generalists, parasites of many fish species in the northern hemisphere. The parasites recorded in our study are all generalists. The intensity of infection with nematodes and acanthocephalans was low. The species composition was very poor, and the species represented two families only. LARSEN et al. (1998), studying the parasite fauna of cod stocks from the Barents Sea, the silled fjord Balsfjord and the open fjord Malangen, concluded that the local parasite fauna was not greatly influenced by the genetic differences between the types of cod, but its composition was largely determined by variations in the abundance of intermediate hosts.

The parasites found in the studied fish are often recorded in this area in the Atlantic cod, except the nematodes Contracaecum sp., which were detected in G. morhua only once (BAZIKALOVA, 1932). In our study, one larva of Contracaecum sp. was found in the stomach of the specimen examined.

The golden cod hosted only four larvae of Anisakis simplex. Larvae of $P$. decipens, recorded in this study on the pyloric caecum and liver often occur also in the muscles of G. morhua from the vicinity of northern Norway. The acanthocephalan E. gadi occurs mostly in the cod alimentary tract (Hemmingsen et al., 1991), which was confirmed in this study.

The parasitic nematodes and acanthocephalans found in this study have a complex life cycle. The first intermediate hosts are invertebrates (Gammarus sp., Pontoporeia femorata, Mysidacea, Isopoda, calanoid and harpacticoid copepods, bristle worms and molluscs). Anisakis simplex, Contracaecum sp. and $P$. decipiens have different fish species as the second intermediate hosts. Hysterothylacium aduncum and E. gadi mature in fishes. The intermediate hosts of E. gadi are most likely amphipods (VALTONEN et al., 1983). Additionally, the parasites mentioned may also have paratenic hosts, among other fishes. All these organisms are the components of cod food, first for juvenile and then for adult fish (Pilecka-Rapacz and Sobecka, 2004; ZaŁachowski, 1985; ZaŁachowski et al., 1976). Probably neither the feeding nor the diet change was affected by the different colouration of the fish examined.

The examined specimen contained no parasites, whose development stages can settle in the host in an active way, as Monogenea or Copepoda. Thus probably in this case the parasite species composition was affected by skin pigmentation.

\section{Acknowledgments}

The authors would like to thank Mr W. Szaszkiewicz, who provided our laboratory with the golden specimen of cod. 


\author{
WPŁYW SPECYFICZNEGO UBARWIENIA ŻYWICIELA NA LICZBE \\ I SKŁAD GATUNKOWY PASOŻYTÓW ZŁOTEGO OSOBNIKA DORSZA \\ GADUS MORHUA L. Z REJONU ŁOWISKA SVÅLBARD
}

\title{
STRESZCZENIE
}

Badania parazytologiczne zostały przeprowadzone na jednym osobniku dorsza Gadus morhua morhua L., o unikatowym złotym ubarwieniu, złowionym w północnowschodnim Atlantyku (łowisko Svålbard) i po raz pierwszy opisanym w literaturze. Dorsz ten został pozyskany podczas przemysłowych połowów ryb tego gatunku o typowym ubarwieniu. Badania parazytologiczne wykazały niewielką liczbę pasożytów wewnętrznych, należących do czterech gatunków nicieni z rodziny Anisakidae i jednego gatunku kolcogłowa z rodziny Echinorhynchidae. Obecność tylko pasożytów wewnętrznych sugeruje, że na skład gatunkowy parazytofauny prawdopodobnie miało wpływ specyficzne złote ubarwienie skóry żywiciela.

Słowa kluczowe: złoty dorsz, Gadus morhua, pasożyty, Anisakidae, Echinorhynchidae, łowisko Svålbard

\section{REFERENCES}

Bazikalowa, A.Y., 1932: Materialy po parazitologii ryb. Sbornik naučno-promyslovyh rabot na Murmane (Parasitological works on fishes. Scientific and commercial investigations in the region of Murman). Snabtehizdat, Moskva, 136-153. (In Russian).

Berenboim, B.I., Dolgov, A.V., Korzhev, V., Yaragin, N.A., 2000: Cod impact on the stock dynamics of shrimp Pandalus borealis in the Barents Sea and its implication in multispecies models. J. Northw. Atl. Fish. Sci. 27: 69-75.

Bigelow, H.B. and Schroeder, W.C., 1953: Fishes of the Gulf of Maine. Fish. Bull., 74 (53): 199.

Hemmingsen, W., Lombardo, I., MacKenzie K., 1991: Parasites as biological tags for cod Gadus morhua L. in northern Norway: a pilot study. Fish. Res. 12: 365-373.

Hemmingsen, W., and MacKenzie, K., 2001: The parasite fauna of Atlantic cod, Gadus morhua L. Adv. Mar. Biol. 40: 1-80.

Jørgensen, H.B.H., Pertoldi, C., Hansen, M.M., Ruzzante, D.E., Loeschcke, V., 2008: Genetic and environmental correlates of morphological variation in a marine fish: the case of Baltic Sea herring (Clupea harengus). Can. J. Fish. Aqua. Sci. 65: 389-400.

Karasev, A., 2003: Katalog parazitov ryb Barenceva morâ (Catalog of fish parasites from the Barents sea). Izdatelstvo PINRO. Murmansk.150 pp. (In Russian)

Larsen, G., Hemmingsen, W., MacKenzie, K., Lysne, D.A., 1998: A population study of cod Gadus morhua L., in northern Norway using otolith structure and parasite tags. Fish. Res. 32 (1): 13-20. doi: 10.1016/S0165-7836(97)00040-4

Pediguero-Alonso, D., Montero, F.E., Raga, J.A., Kostadinova, A., 2008: Composition and structure of the parasite faunas of cod Gadus morhua L. (Teleostei: Gadidae), in the North east Atlantic. Parasitic \& Vectors. 2008; 1: 23. Published online 2008 July 18. doi: 10.1186/1756-3305-1-23 
Pilecka-Rapacz, M., Sobecka, E., 2004: Parasites of young Baltic cod, Gadus morhua callarias L. in the Gulf of Puck, Poland. Acta Ichth. et Piscat. 34 (2): 235 240.

Więcaszek, B., Antoszek, A., Antoszek, J., 2009: Comparative study of biometric characters of the "golden" cod and a sample of cod of typical pigmentation (Gadus morhua morhua L.) captured in the Svålbard bank. EJPAU (Topic: Fisheries) 12 (2).

Valtonen, E.T., Maren, M.J., Timola, O., 1983: A note on the intermediate hosts of Echinorhynchus gadi Zoega in Müller (Acanthocephala) in the Baltic Sea. Aquilo Seria Zoologica 22: 93-97.

ZaŁachowski, W., 1985: Amount and composition of food of cod (Gadus morhua) in the southern Baltic in 1977-1982. Acta Ichth. et Piscat. 15(2): 96-117.

ZaŁachowski, W., Szypula, J., Krzykawski, S., Krzykawska, I., 1976: Composition and amount of food consumed by sprat, herring and cod in the Southern Baltic in the years 1971-1974. ICES C.M. 1976/P:23. Baltic Fish Committee, 1-7.

Received 2010-04-19 